\title{
САЙХАН-ОВООГИЙН НҮҮРСНИЙ ШИНЖ ЧАНАР БА ПИРОЛИЗЫН СУДАЛГАА
}

\author{
Я. Даваажав, Б.Пүрэвсүрэн, Х.Серикжан, С. Батбилэг, Э.Ууганжаргал \\ ШУА, Хими, Хими-Технологийн ХУрээлэн, b_purevsuren@yahoo.com
}

\begin{abstract}
Манай орон нүҮрсний арвин их нөөцтэй бөгөөд зарим ордуудын нүүрсний судалгаа нэлээд өргөн хүрээтэй хийгдсэн байдаг. Харин Сайхан-Овоогийн ордын нүүрс нь төдийлөн судлагдаагүй учир энэ ордын нүүрсийг судалгааны обьектоор сонгон авч нүүрсний техникийн шинж чанарын ҮзҮүлэлтүүдийг тодорхойлж, нүүрсэн дэх хүхрийн хэлбэруүдийг тогтоон, пиролизын бүтээгдэхүүний гари, хатуу үлдэгдэл дэххүхрийн хэлбэрүүдийн агуулга, шингээх, шүҮх чадвар зэргийг судлан тогтоолоо. Мөн нүүрсний бүтэи, үнсний макро, микро элементүүдийг нил улаан туяаны спектрометр, рентген флуорениениийн спектрометрээр тодорхойлов.
\end{abstract}

Түлхүур үг: Нүүрс, Пиролиз, Идэвхжүүлэлт, Ерөнхий хүхэр, эрдэс бүрэлдэхүүн

\section{Оршил}

Манай улсын хэмжээнд 40 орчим уурхайгаас 70 гаруй аж ахуй нэгж байгууллага нүүрс олборлон цахилгаан станц, албан байгууллага, айл өрхийн хэрэгцээнд эрчим хүч, дулааны эх үүсвэр болгон түлшинд ашиглах зорилгоор олборлож байна. Манай орны нүүрсний нөөц 152 тэрбум.тонн ба дэлхийд нүүрсний нөөцөөрөө 12-р байр эзэлж байна. Техник технологийн хөгжлийн хурдац өндөр байгаа өнөө үед байгалийн нөөц баялаг тэр дундаа нефть ба хатуу түлшийг боловсруулан эргэлтэнд оруулж үр дүнтэй ашиглах нь улс орны эдийн засгийн тулгамдсан асуудал болж байна. [1]. Иймээс тухайн нүүрсний ордуудад бүрэн судалгаа шинжилгээ хийж нүүрсний ангилал , ашиглах чиглэлийг тогтоох ажил бидний өмнө тавигдсан билээ. Сайхан Овоогийн нүүрсний орд нь Булган аймгийн Сайхан сумын төвөөс баруун хойш 22 км-т оршдог, геологийн бүтцээрээ дунд юрийн үеийн настай хурдсаас тогтсон юм. Орд нь доод суурийн ба дээд ашигт гэсэн 2 давхаргаас тогтоно. 19881999 онд геологийн үнэлгээний ажил хийгдэж ордын төв хэсгээр өрөмдлөг хийж нүүрсний давхаргууд нь бялхмал чулуулгын доогуур сунасан хэлбэрээр үргэлжилж байгааг илрүүлж, нөөцийг $\mathrm{C}_{1}=23950.5$ мян.т, $\mathrm{C}_{2}=10714.4$ мян.т нийтдээ 34.7 сая.тн гэж тогтоожээ.[2] Бид харьцангуй бага судлагдсан энэхүү ордын нүүрснээс дээж авч техник шинж чанарууд, органик ба эрдэс хэсгийн элементийн найрлага, пиролизын бүтээгдэхүүнүүдийн гарц зэргийг судлах зорилт тавьж ажиллав.

Судалгааны материал, аргазүй

Судалгаанд уг ордын нүүрснээс аналитик дээж бэлтгэн нүүрсний техник үзүүлэлтүүдийг холбогдох стандарт аргуудаар [3] тухайлбал чийг-УСТ656-79, 
дэгдэмхий бодисын гарц-УСТ654-79, үнслэг-УСТ652-79, илчлэг-УСТ669-87, хүхрийн агуулга-УСТ895-79 зэрэг аргуудаар тодорхойлов. Мөн пиролизын хатуу үлдэгдлийг усны уураар идэвхжүүлж шингээх чадварыг нь тодорхойлов.[4]

\section{Нүурсний пиролизын арга}

Судалгааны объект болгон сонгож авсан нүүрсний дээжинд пиролизын туршилтуудыг өөрсдийн зохион бүтээсэн төмөр реторт бүхий пиролизын лабораторийн томруулсан төхөөрөмжинд хийж гүйцэтгэв.Ретортын эзэлхүүний 1/3-д нь 2-5 мм ширхэглэлтэй болтол нь нунтагласан нүүрсний дээжнээс хийж ретортыг асбестан жийргэвч ашиглан хий гарахааргүй бин битүү таглана. Ретортоос гарсан төмөр хоолойг резинэн бөглөөний тусламжтайгаар шилэн хөргөгчтэй холбож хөргөгчийн нөгөө үзүүрийг хүлээн авагч колботой холбоно. Хөргөгчийн гадна талаас хүйтэн усаар хөргөнө .Ингэж холбосны дараа ретортыг халааж эхэлнэ. Зуухны халаалтын температурыг милливольтметрээр хянаж, зуухны температурыг 600-700 ${ }^{\circ} \mathrm{C}$ хүртэл халааж пиролизыг явуулна. Пиролизоор үүссэн уур хийн холимогийг шилэн хөргөгч дундуур нэвтрүүлэн хөргөгчийг хөргөх замаар шингэрүүлж давирхай байдлаар хүлээн авагч колбонд тосч авна.Шингэрээгүй хий гадагшилна.

Туршилт дууссаны дараа халаагч зуухыг салгаж, хөргөөд реторт дотор үлдсэн хатуу үлдэгдэл, хүлээн авагч колбонд гаргаж авсан давирхай ба задралын усыг хамтад нь жигнэж гарцыг тодорхойлно. Дараа нь давирхай ба усыг халаагч юүлүүрийн тусламжтайгаар салгаж тус тус жигнэнэ. Хуурай үлдэгдэл , давирхай, задралын ус зэргийн нийлбэр жинг жингийн аргаар тодорхойлно. Туршилтыг давирхай үүсэхгүй болтол нь явуулна.

\section{Нүурсийг усны уураар идэвхжүүлэх арга}

Нүүрсний пиролизоор гарган авсан хатуу үлдэгдлийг дараах аргаaр идэвхжүүлэв.

Пиролизын аргаар гарган авсан хатуу үлдэгдлээс 10 г дээж жигнэн авч кварцан хоолойд хийж доороос нь усны халуун уураар үлээлгэх замаар $800{ }^{\circ} \mathrm{C}-д 2$ цагийн турш идэвхжүүлэлтийг явуулав. Идэвхжүүлэгч зуухны температурыг термопараар хянана.

Судалгааны үр дүн, дүгнэлт

Сайхан Оовоогийн нүүрсний техникийн үндсэн үзүүлэлтүүд болох чийг үнслэг, дэгдэмхий бодисын гарц, илчлэгийг тодорхойлж үр дүнг 1-р хүснэгтэд үзүүлэв. 
$1-p$ хүснэгт

\begin{tabular}{|c|c|c|c|c|c|c|}
\hline \multirow[t]{2}{*}{ Дээж } & \multirow{2}{*}{$\begin{array}{c}\text { Чийг, \% } \\
\mathrm{W}^{\mathrm{a}}\end{array}$} & \multicolumn{2}{|c|}{ Үнслэг, \% } & \multicolumn{2}{|c|}{ Дэгдэмхий бодис ,\% } & \multirow{2}{*}{$\begin{array}{c}\text { Илчлэг } \\
\text { чанар } \\
\mathrm{Q}^{\text {daf }} \text {,ккал/кг }\end{array}$} \\
\hline & & $\mathrm{A}^{\mathrm{a}}$ & $\mathrm{A}^{\mathrm{d}}$ & $\mathrm{V}^{\mathrm{a}}$ & $\mathrm{V}^{\text {daf }}$ & \\
\hline $\begin{array}{c}\text { Сайхан-Овоо } \\
\text { нүүрс }\end{array}$ & 2,24 & 10,35 & 10,58 & 7,15 & 8,17 & 8052,46 \\
\hline
\end{tabular}

1-р хүснэгтээс үзэхэд Сайхан овоогийн нүүрс нь чийг ба дэгдэмхий бодисын гарц багатай илчлэг өндөртэй байна. Тухайлбал дэгдэмхий бодисын гарц нь нилээд сонирхол татсан үр дүн бөгөөд энэ үзүүлэлтийг бид нилээд олон давталттайгаар нарийвчлан тодорхойлсон бөгөөд энэ нь уг ордын нүүрсийг чулуун нүүрснээс антрацит руу шилжиж байгаа сайн чанарын нүүрс болохыг харуулж байна гэж үзлээ. Мөн илч үүсгэх чадвар өндөр байгаа нь энэхүү нүүрс нь нилээд сайн чанарын нүүрс болохыг давхар баталж байна. Шатамхай хатуу түлшний дэгдэмхий бодисын гарц нь түүний органик массын халуун тэсвэрлэх чадварыг тодорхойлдог бөгөөд нүүрсжилтийн зэрэг ихсэх тусам органик массынх нь халуун тэсвэрлэх чадвар нэмэгддэг.

Нүүрс ба нефтэнд байгаа хүхрийн агуулга их байвал байгаль орчинд сөрөг нөлөө үзүүлдэг. Иймд энэ нүүрсний хүхрийн агуулгыг төрөл бүрийн хэлбэрүүдээр нь химийн анализын стандарт аргаар тодорхойлж үр дүнг 2-р хүснэгтэнд үзүүлэв.

2-р хуснэгт

Эх дээжний хүхрийн хэлбэрүүдийн агуулга

\begin{tabular}{|c|c|c|c|c|}
\hline Ордын нэр & $\begin{array}{l}\text { Сульфат } \\
S_{\mathrm{SO}_{4}}^{a}, \%\end{array}$ & $\begin{array}{l}\text { Пирит } \\
S_{S}^{a}, \%\end{array}$ & $\begin{array}{l}\text { Органик } \\
S_{O P}^{a}, \%\end{array}$ & $\begin{array}{c}\text { Ерөнхий хүхэр } \\
S_{\text {total }}^{a}, \%\end{array}$ \\
\hline Сайхан-Овоо & 0,013 & 0,018 & 0,32 & 0,35 \\
\hline
\end{tabular}

Хүхрийн агуулгыг хэлбэр тус бүрээр авч үзвэл эх нүүрсний сульфатын хүхэр 0.013\%, пиритийн хүхэр 0.018 \% ба органик хүхэр $0.32 \%$ байна. Хүхрийн агуулгыг нийлбэр хүхэрт тооцож үзвэл: 91,1\% органик, 5,14\% пирит, үлдсэн 3,71 \% сульфатын хүхэр агуулагдаж байна. Энэ дүнгээс үзэхэд Сайхан -Овоогийн нүүрсийг харьцангуй хүхэр багатай нүүрсэнд тооцож болохоор байна.

Бидний судалгааны ажлын нэг хэсэг нь 3-4мм ширхэглэгтэй дээж бэлтгэн пиролизод оруулж хатуу, шингэн,хийн бүтээгдэхүүнийх нь гарцыг тодорхойлж хагас коксыг нь идэвхжүүлэх ажил юм. Сайхан- Овоогийн нүүрсний пиролизын туршилтын дүнд гарган авсан бүтээгдэхүүнүүдийн гарцыг тодорхойлж 3-р хүснэгтэнд үзүүлэв. 
3-р хүснэгт

Сайхан-Овоогийн нүҮрсний пиролизын бүтээгдэхүҮний гари

\begin{tabular}{|c|c|l|l|l|}
\hline Дээж & $\begin{array}{c}\text { Пиролизын } \\
\text { температур, }^{0} \mathrm{c}\end{array}$ & $\begin{array}{c}\text { Давирхай+ус } \\
\%\end{array}$ & $\begin{array}{c}\text { Хатуу } \\
\text { Үлдэгдэл, \% }\end{array}$ & $\begin{array}{c}\text { Хий ба } \\
\text { алдагдал, \% }\end{array}$ \\
\hline \multirow{3}{*}{ Сайхан-Овоо } & \multirow{2}{*}{$600-650$} & 5,7 & 91,0 & 3,3 \\
& & 5,7 & 90,5 & 3,9 \\
& & 4,0 & 91,3 & 4,7 \\
& & 4,8 & 90,1 & 3,7 \\
\hline \multicolumn{2}{|c|}{ Дундаж } & 5,3 & 91,0 & 4,2 \\
\hline
\end{tabular}

Дээрхи хүснэгтээс харахад нүүрстөрөгжсөн хатуу үлдэгдэлийн гарц 90,8\% , давирхай ба задралын усны нийлбэр 5,3 \% байгаа нь нүүрсжилтийн насжилт ихсэх тусам давирхайн гарц бага байдгийг харуулж байна. Сайхан овоогийн нүүрсний пиролизын хатуу үлдэгдэл буюу хагас кокс нь бүхэллэг чанартай, нүх сүвэрхэг бүтэцтэй байгаа нь бидний сонирхлыг татаж түүний шинж чанарыг нарийвчлан тодорхойлж тухайлбал түүний техникийн үзүүлэлт ба ерөнхий хүхрийн агуулга, түүний хэлбэрүүдийг тодорхойлж үр дүнгүүдийг 4 ба 5-р хүснэгтэнд үзүүлэв.

Пиролизын хатуу үлдэгдэл(хагас кокс)-ийн техник анализын дүн

\begin{tabular}{|c|c|c|c|}
\hline Дээж & Чийг, $\mathrm{W}^{\mathrm{a}} \%$ & Үнслэг, $\mathrm{A}^{\mathrm{a}} \%$ & Дэгдэмхий бодис, $\mathrm{V}^{\mathrm{a}} \%$ \\
\hline Сайхан-Овоо & 0,17 & 9,02 & 0,42 \\
\hline
\end{tabular}

Хагас коксын дэгдэмхий бодисын гарц эх дээжийнхтэй харьцуулахад 17 дахин багассан байна. Хагас кокс нь эх дээж нүүрснээсээ нүүртөрөгчийн агуулга их, дэгдэмхий бодис болон устөрөгчийн агуулга бага байдгаараа ялгагддаг.

5-р хуснэгт

Пиролизын хатуу үлдэгдэл дахь хүхрийн агуулга

\begin{tabular}{|c|c|c|c|c|}
\hline Ордын нэр & $\begin{array}{c}\text { Сульфат } \\
S_{S_{4}}^{a}, \%\end{array}$ & $\begin{array}{c}\text { Пирит } \\
S_{S}^{a}, \%\end{array}$ & $\begin{array}{c}\text { Органик } \\
S_{O P}^{a}, \%\end{array}$ & $\begin{array}{c}\text { Ерөнхий хүхэр } \\
S_{\text {ОБщ, }}^{a} \%\end{array}$ \\
\hline $\begin{array}{c}\text { Сайхан-Овоо (пиролизын } \\
\text { хатуу үлдэгдэл) }\end{array}$ & 0,0052 & 0,045 & 0,35 & 0,40 \\
\hline Сайхан-Овоо (эх дээж) & 0,013 & 0,018 & 0,32 & 0,35 \\
\hline
\end{tabular}


Дээрх хүснэгтэд эх дээж нүүрс болон пиролизын хатуу үлдэгдэл дэхь хүхрийн хэлбэрүүдийг тодорхойлж харуулав. Хүснэгтээс харахад пиролизын хатуу үлдэгдэл дэх ерөнхий хүхэр нь 0,40 \% байгаа нь эх дээжний ерөнхий хүхрийн (Хүснэгт 2)-хээс 1,14 дахин ихэссэн байна. Энэ нь хүхэр нүүрсний органик массын задралын явцад төдийлөн хувиралд орж дэгдэмхий нэгдлүүд үүсгэдэггүй нүүрсний хатуу үлдэгдэл ба эрдэс хэсэгтэй хамт үлддэг болохыг харуулж байна. Энэхүү хатуу үлдэгдэл нь нүх сүвэрхэг чанартай байгаа учраас түүнийг шингээгч болгон ашиглах зорилгоор идэвхжүүлж нүх сүвэрхэг чанарыг нь дээшлүүлэн шингээх чадварыг нь иод болон метилен хөх ашиглан тогтоох туршилтын үр дүнг 6-р хүснэгтэнд үзүүлэв.

6-р хүснэгт

\begin{tabular}{|c|c|c|c|c|c|}
\hline Дээж & Температур, ${ }^{\circ} \mathrm{C}$ & $\begin{array}{c}\text { Ширхэглэл, } \\
\text { Мм }\end{array}$ & $\begin{array}{c}\text { ИдэвхжүY- } \\
\text {-лэлтийн } \\
\text { хугацаа, цаг }\end{array}$ & $\begin{array}{c}\text { Метилен } \\
\text { хөхийн } \\
\text { шингээлт, } \\
\text { мг/г }\end{array}$ & $\begin{array}{c}\text { Иодын } \\
\text { шингээлт, } \\
\text { \% }\end{array}$ \\
\hline \multirow{2}{*}{ Сайхан - Овоо } & Анхны дээж & $0,6-1,0$ & 0 & шингээгүй & 1,26 \\
\hline & 850 & $0,6-1,0$ & 1 & 12,08 & 30,23 \\
\hline
\end{tabular}

Дээрхи хүснэгтүүдээс харахад усны уураар идэвхжүүлсний дараа нүүрсний нүх, сүвэрхэг чанар нэмэгдсэн бөгөөд метилен хөхийн шингээлт $12,08 \mathrm{Mг} / г$, иодын шингээлт 30,23\% буюу эх дээжнээс шингээлт нь 24 дахин ихэссэнээр харагдаж байна. Энэ нь Сайхан овоогийн нүүрснээс сайн чанарын шингээгч шүүгч материал гарган авч хэрэглэж болохыг харуулж байна.

Сайхан-Овоогийннүүрсийгпиролизынбаидэвхжүүлэлтийнаргаарболовсруулж утаагүй түлш, шингээгч, шүүгч материал гарган авч хэрэглэхэд түүнд агуулагдаж байгаа цацраг идэвхит элементүүдийг тодорхойлох нь чухал юм Иймд Сайхан овоогийн ордын нүүрс, үнсэнд цацраг идэвхит элементүүдийн болон, эрдсийн агуулгуудыг гаммаспектрометрийн, Рентген флуоренценцийн спектрометр аргаaр тодорхойлж үр дүнгүүдийг 2-р зураг, 7,8-р хүснэгтэнд үзүүлэв.

7-р хүснэгт

Сайхан-Овоогийн ордын нүҮрсний нүҮрс, үнсэнд агуулагдах ияацраг идэвхит элементүүдийн агуулга

\begin{tabular}{|c|c|c|c|c|c|c|c|}
\hline \multirow[t]{2}{*}{ Дээж } & \multicolumn{3}{|c|}{$\begin{array}{l}\text { Изотопын идэвх } \\
\text { Бк/кг } \\
\end{array}$} & \multicolumn{3}{|c|}{$\begin{array}{c}\text { Элементийн агуулга, } \\
\text { г/т }\end{array}$} & \multirow{2}{*}{$\begin{array}{c}\text { Радийн } \\
\text { эквивалент, } \\
\text { Бк/кг } \\
\end{array}$} \\
\hline & Ra-226 & Th-232 & $\mathrm{K}-40$ & $\mathrm{U}, \Gamma / \mathrm{T}$ & Th, г/T & $\mathrm{K}, \Gamma / \mathrm{T}$ & \\
\hline НүYрс & 67.4 & 4.3 & 259.1 & 5.5 & 1.1 & 0.9 & 95.06 \\
\hline Үнс & 393.8 & 53.8 & 1036.4 & 31.88 & 13.25 & 3.34 & 332.71 \\
\hline
\end{tabular}


Хүснэгт 7-оос харахад нүүрсний үнсэнд уран, тори, кали зэрэг цацраг идэвхт элементийн хэмжээ эх нүүрстэй нь харьцуулахад олон дахин ихэссэн байна. Энэ нь нүүрсний үнсийг хараа хяналтгүйгээр хаяж байгаль орчин бохирдуулахаас сэргийлэх шаардлагатайг харуулж байна.

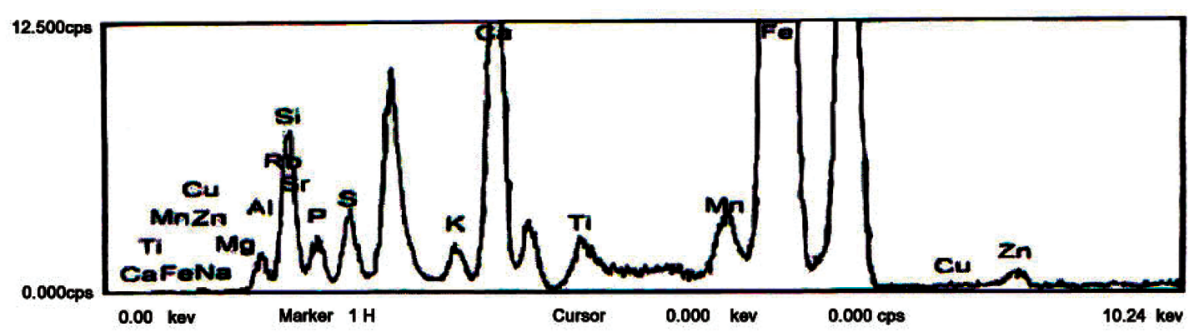

1-р зураг. Сайхан овоогийн нүүрсний үнсний Рентген флуоренценцийн спектрометр

8-р хүснэгт

Сайхан овоогийн ордын нүүрсний үнсэнд агуулагдах эрдсийн найрлага

\begin{tabular}{|c|c|c|c|}
\hline \multicolumn{2}{|c|}{ Элемент (\%) } & $\mathrm{Na}_{2} \mathrm{O}$ & Оксид (\%) \\
\hline $\mathrm{Na}$ & 0,000 & $\mathrm{MgO}$ & 2,530 \\
\hline $\mathrm{Mg}$ & 1,526 & $\mathrm{Al}_{2} \mathrm{O}_{3}$ & 8,199 \\
\hline $\mathrm{Al}$ & 4,339 & $\mathrm{SiO}_{2}$ & 17,066 \\
\hline $\mathrm{Si}$ & 7,978 & $\mathrm{P}_{2} \mathrm{O}_{5}$ & 3,056 \\
\hline $\mathrm{P}$ & 1,334 & $\mathrm{SO}_{3}$ & 2,145 \\
\hline $\mathrm{S}$ & 0,859 & $\mathrm{~K}_{2} \mathrm{O}$ & 0,437 \\
\hline $\mathrm{K}$ & 0,363 & $\mathrm{CaO}_{2}$ & 4,815 \\
\hline $\mathrm{Ca}$ & 3,441 & $\mathrm{TiO}_{2}$ & 0,503 \\
\hline $\mathrm{Ti}$ & 0,302 & $\mathrm{Mn}_{2} \mathrm{O}_{3}$ & 0,430 \\
\hline $\mathrm{Mn}$ & 0,299 & $\mathrm{Fe} \mathrm{O}_{3}$ & 60,212 \\
\hline $\mathrm{Fe}$ & 42,114 & $\mathrm{CuO}_{2}$ & 0,031 \\
\hline $\mathrm{Cu}$ & 0,024 & $\mathrm{ZnO}_{2}$ & 0,265 \\
\hline $\mathrm{Zn}$ & 0,213 & $\mathrm{Rb}_{2} \mathrm{O}$ & 0,035 \\
\hline $\mathrm{Rb}$ & 0,032 & $\mathrm{SrO}$ & 0,277 \\
\hline $\mathrm{Sr}$ & 0,234 & - & - \\
\hline $\mathrm{O}$ & 36,942 & & \\
\hline
\end{tabular}


8-p хүснэгтээс харахад $\mathrm{Fe}-42.11 \%, \mathrm{Fe}_{2} \mathrm{O}_{3}-60.21 \%$ хамгийн өндөр агуулгатай байна. Мөн $\mathrm{Fe}_{2} \mathrm{O}_{3}+\mathrm{CaO}+\mathrm{MgO}+\mathrm{Na}_{2} \mathrm{O}+\mathrm{K}_{2} \mathrm{O} / \mathrm{SiO}_{2}+\mathrm{AI}_{2} \mathrm{O}_{3}+\mathrm{TiO}_{2} \gg 1$ байгаа учир Сайхан овоогийн нүүрсний үнс нь суурилаг (1-ээс бага байвал хүчиллэг) шинж чанартай байна гэж тооцож болох юм.

Сайхан-Овоогийн нүүрсний НУТ - спектрометрийг 2-р зурагт үзүүлэв.

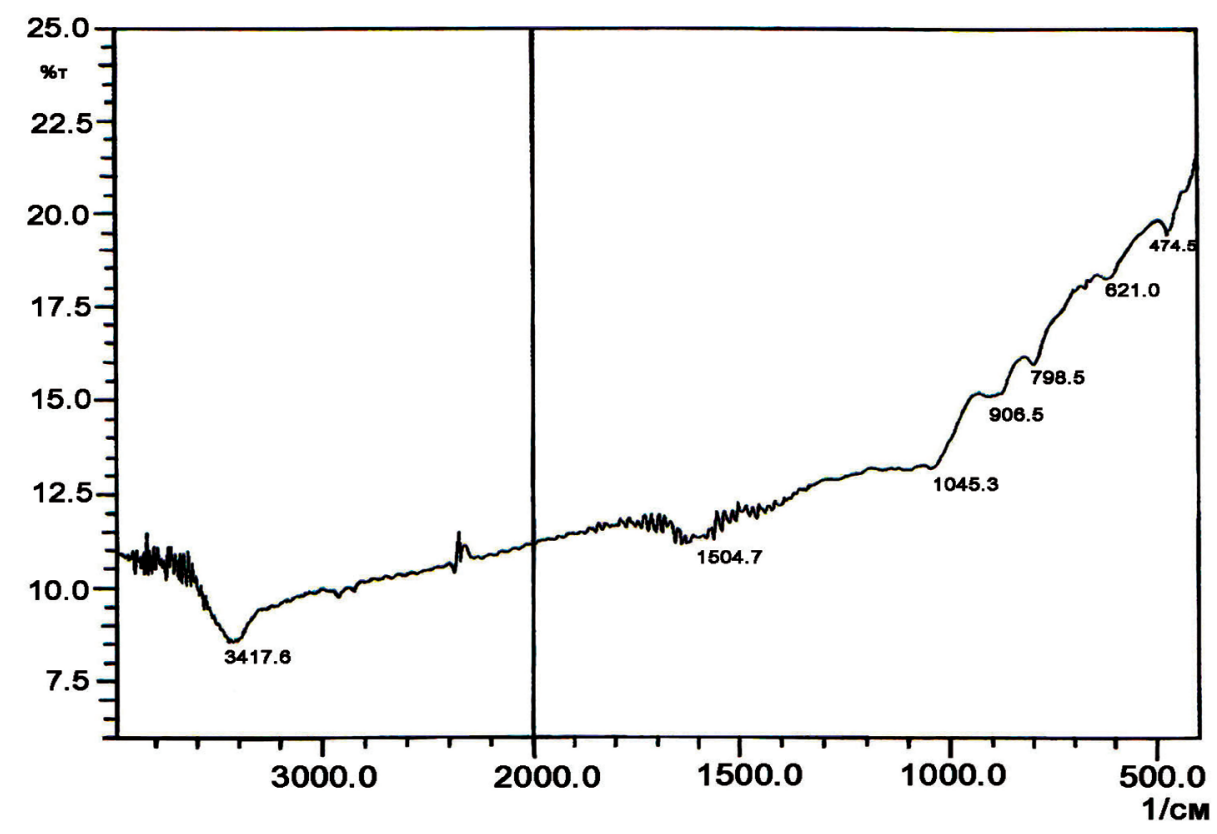

2-р зураг.Сайхан-Овоогийн нүурсний НУТ спектр

НУТС-ээс үзэхэд шингээлтийн зурвасууд нь эрчим багатай хурц биш, мохоо салаалж үргэлжилсэн байдалтай байгаа нь нүүрсний органик масс ба эрдэс хэсэг нь полимержсон хэлбэртэй байгааг харуулж байна. Полимержсон органик массад байгаа янз бүрийн халагч бүхий ароматик цагирагт нэгдлүүдийн эрчим багатай шингээлт 600-900 $\mathrm{cm}^{-1}$-д, алифатик болон ароматик $\mathrm{CH}$, этилийн эфирийн бүлэг бүхий нэгдлүүдийн эрчим багатай шингээлт нь $1045 \mathrm{~cm}^{-1}$-д, нүүрсний органик массад байгаа карбоксил бүлэг-СООН, этилийн эфирийн -CO-O- болон кетоны НCO карбонилийн бүлгүүдийн нэлээд өргөн шингээлт нь $1604 \mathrm{~cm}^{-1}$-д, алифатикметиний, метилений, метилийн бүлгүүдийн эрчим багатай шингээлт 2800-2900 см ${ }^{1}$-д гидроксилын бүлэг болон ассоциалагдсан гидроксилын бүлгүүдэд хамаарагдах эрчим сайтай шингээлт 3400-3500 $\mathrm{cm}^{-1}$-д тус тус ажиглагдаж байна. 


\section{Дүгнэлт}

1. Сайхан-Овоогийн дээжинд хийсэн шинжилгээний дүнд: чийг-2.24\%, үнслэг$10.56 \%$ шатамхай массад тооцсоноор дэгдэмхий бодисын гарц $8,17 \%$ байгааг тодорхойлов.

2. Сайхан овоогийн нүүрсний дэгдэмхий бодисын гарц бага, илчлэг өндөр байгаа нь чулуун нүүрснээс антрацит руу шилжиж байгаа сайн чанарын чулуун нүүрс болохыг харуулж байна.

3. Нүүрсэн дэх нийт хүхрийн агуулга $0,35 \%$ байгаа нь хүхэр багатайд тооцогдох ба хагас коксод $0,40 \%$ байгаа нь энэ нүүрсийг ашиглахад байгаль орчин болон тоног төхөөрөмжинд үзүүлэх хортой нөлөөлөл багатай ба металлургийн үйлдвэрт хэрэглэхэд ширэмний чанарт муугаар нөлөөлөхгүй гэж үзэв.

4. Пиролизийн хатуу үлдэгдэлийн гарц их 90,8\% байгаa нь хагас коксыг нь металургийн үйлдвэрт мөн айл өрхийн хэрэгцээнд утаагүй түлш болгон хэрэглэхээс гадна, усны уураар идэвхжүүлж шүүгч, шингээгч материал болгон ашиглах бүрэн боломжтойг иодын болон метилен хөхийг уусмалаас нь шингээх чадварыг тодорхойлох замаар тогтоов.

5. Үнсэн дэх цацраг идэвхит элементийн агуулга нүүрснийхээс хэд дахин илүҮ байгаа нь үнсийг нь ямар нэгэн боловсруулалт хийхгүйгээр зам, барилгын материалын үйлдвэрт нэмэлт болгон хэрэглэх боломжгүй гэж үзлээ.

6. Үнсний химийн найрлагаас үзэхэд суурилаг шинжтэй үнс болохыг тодорхойлов.

7. Цахиурын ислийн агуулга харьцангуй бага байгаа нь үнсний хайлах температур бага болохыг харуулж байна.

Ашигласан материал

[1] А.И.Камнева, В.В.Платонов, “Теоретические основы химии горючих ископаемых”, Москва. 1990,с 66,

[2] П.Очирбат нар. Монгол улсын нүүрсний аж үйлдвэр XX зуунд, ном Улаанбаатар, 2002

[3] Е.М.Тайц, И.А.Андреева, “Методы анализа и испьттания углей”, Москва.1983, с 97-99,.

[4] Я.Даваажав, С.Батбилэг, Х.Серикжан, Б.Пүрэвсүрэн, Э.Ууганжаргал. “Сайхан-Овоогийн нүүрсний судалгаа” ХХТХ ба ШУТИС-ийн МТС-ийн хамтарсан эрдэм шинжилгээний Хими-2009 хурал, 2009-5-1, Улаанбаатар хот 


\section{Characterization}

\section{Investigation on characterization and pyrolysis of coal from Saikhan-Ovoo deposit}

Ya. Davaajav, B.Purevsuren, Kh. Serikjan, S. Batbileg, E. Uuganjargal Institute of Chemistry and chemical Technology,MAS.

Have been determined main technical characteristics of coal from Saikhan-Ovoo deposits: moisture $\mathrm{W}^{\mathrm{a}}-2.24 \%$, ash, $\mathrm{A}^{\mathrm{a}}-10.56 \%$, volatile matter, $\mathrm{V}^{\text {daf }}-8.17 \%$ caloric value, $\mathrm{Q}_{0}-$

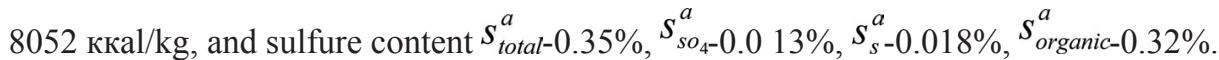

Saikhan-Ovoo coal was tested by pyrolysis experiments and determined yields of pyrolysis hard residue- $90.8 \%$, tar and water-5.3\%, and gases-3.8\%.The pyrolysis hard residue had been activated by steam and the adsorbing was ability increased which measured with iodine and methyleneblue.

The X-ray and analysis of coal ash showed that ash has alkaline character. 